\title{
Nutlet micromorphology and its taxonomic utility in Lamium L. (Lamiaceae)
}

\author{
Katarzyna Krawczyk • Katarzyna Głowacka
}

Received: 23 January 2014/ Accepted: 23 January 2015/Published online: 12 February 2015

(C) The Author(s) 2015. This article is published with open access at Springerlink.com

\begin{abstract}
This paper presents results of examination of fruit surface in the genus Lamium L. (Lamiaceae) using scanning electron microscopy (SEM). The purpose of this study was to define new features that differentiate taxa difficult to identify on the basis of macromorphological features, such as species of hybrid origin and subspecies within Lamium. The results of our research show that the SEM analysis of fruit surface allowed defining new diagnostic features for almost all studied representatives of the genus Lamium except for $L$. confertum from $L$. coutinhoi and L. album subsp. album from L. album subsp. barbatum. The most useful feature in distinguishing the examined species was cuticle striation. I turn, the type of secondary sculpturing of the cell walls divided the species studied into two main groups. One of them consisted of four taxa $(L$. album, $L$ flexuosum, $L$. garganicum, $L$. orvala) with thickenings of the cell walls in the form of irregular ridges and tubercles. The other one comprised all the remaining species, with cell wall thickenings forming regular papillae. The only species which could not be qualified to any of these groups was L. moschatum. The obtained results demonstrated also high similarity of $L$. galeobdolon to the remaining species of Lamium, especially L. flexuosum and
\end{abstract}

Handling editor: Louis P. Ronse De Craene.

\section{K. Krawczyk ( $\square)$}

Department of Botany and Nature Protection, University of

Warmia and Mazury in Olsztyn, Plac Łódzki 1, 10-727 Olsztyn, Poland

e-mail: katarzyna.krawczyk@uwm.edu.pl

\section{K. Głowacka}

Department of Plant Physiology, Genetics and Biotechnology, University of Warmia and Mazury in Olsztyn, Oczapowskiego 1A, 10-719 Olsztyn, Poland
L. orvala. This observation provides an argument for the inclusion of $L$. galeobdolon to the genus Lamium.

Keywords Lamium · Taxonomy $\cdot$ Nutlet $\cdot$ SEM · Micromorphology $\cdot$ Lamiaceae

\section{Introduction}

Dead-nettle Lamium L. (Lamiaceae) is a genus comprising 25 species of herbaceous plants (Govaerts et al. 2010). Morphological diversity within this genus is relatively low. Representatives of particular species differ in details of flower structure, leaf shape or their arrangement on the stem. Part of the taxa distinguished in Lamium are difficult to identify because of the very subtle morphological features that differentiate them. This particularly applies to $L$. incisum and L. confertum, which are polyploidal species of hybrid origin (Jörgensen 1927; Taylor 1991; Dvořáková 2000). L. incisum is easy to confuse with $L$. purpureum, while $L$. confertum shows a very high morphological similarity to L. amplexicaule (Szafer et al. 1986; Dvoŕáková 2000). There are also difficulties with the delimitation of some subspecies distinguished within Lamium. For instance, one of the controversial taxa is L. garganicum subsp. laevigatum, distinguished on the basis of pubescence and the shape of the upper lip of the corolla (Arcangeli 1882; Ball 1972), but combined into one taxon with L. garganicum subsp. garganicum by some researchers (Mennema 1989; Govaerts et al. 2010). Also the systematic order within the genus Lamium is a disputable issue. On the basis of morphological features, the genus is divided into three subgenera: Lamium, Orvala and Galeobdolon (Mennema 1989). In the biggest one-subgenus Lamium, there are three sections: Amplexicaule, Lamiotypus and 
Lamium. The division into subgenera has been set taking into account: pubescence of anthers, shape and pubescence of calyx, shape of corolla tube and locations of floral leaves. Division of subgenus Lamium into three sections also relies on the shape of corolla tube and the presence or absence of floral leaves. Recently, this classification, determined solely on the basis of morphological features, has been undermined by phylogenetic studies (Bendiksby et al. 2011), however a new division has not yet been proposed.

Since macromorphological features are often an insufficient criterion for identification of some representatives of Lamium, and they fail to fully reflect phylogenetic relationships within the genus, we decided to search micromorphological features characteristic for the representatives of Lamium. According to the study conducted on a group of about 5,000 species of plants, a very valuable taxonomic criterion at the level of species, order, and family is the sculpturing of the seed surface (Barthlott and Voit 1979; Barthlott 1981). The usefulness of mericarp morphology, anatomy and pericarp structure in taxonomy was also proved by numerous studies carried out in Lamiaceae at various taxonomical levels (Husain et al. 1990; Demissew and Harley 1992; Ryding 1992, 1994, 1995; Marin et al. 1994, 1996; Oran 1996; Budantsev and Lobova 1997; Jamzad et al. 2000; Guerin 2005; Moon and Hong 2006; Salmaki et al. 2008; Kahraman et al. 2011; Sat1l et al. 2012). For instance, Marin et al. (1994) and Ryding (1995) concluded that nutlet characters were potentially useful within Lamiaceae at the level of section, genus and species. Studies on Stachys L. showed that nutlet micromorphological characters appear to be useful in distinguishing infrageneric groups (Demissew and Harley 1992) and in the species-level taxonomy (Sat1l et al. 2012). In Salvia L., one of the largest genera of Lamiaceae, it has been shown that gross morphology of nutlets and their sculpturing pattern are variable and taxonomically useful at a species level (Oran 1996; Kahraman et al. 2011). In all these studies, the analysis based on scanning electron microscopy (SEM) has been successfully applied.

The purpose of this study was to provide a detailed description of fruit micromorphology in Lamium by using SEM and to evaluate the systematic significance of such characteristics in the light of the variation between taxa of the genus. The observed variability was also analyzed in relation to the evolutionary history of this genus.

The subject of our research was fruit characteristic for the genus Lamium, i.e., schizocarp splitting apart into four mericarps (nutlets). Each of them contains one seed covered with a dry, nonsplitting, leathery pericarp. The mericarps are ovoid, flat at the apex, triangular. They possess elaiosomes, the presence of which indicates adaptation to seed dispersal by myrmecochory (Dvořáková 2000).
Morphological variation of fruits is observed between species with respect to fruit size, color and the presence or absence of convex spots on their surface. Micromorphological variability of fruits in the genus Lamium has not been widely studied until now. To date this variability has been described only for the subspecies of $L$. galeobdolon (L.) L. (Czarna and Bednorz 2011), which by some taxonomists (e.g., Dvořáková 2000; Mirek et al. 2002; Rothmaler 2007) is excluded to the separate genus as Galeobdolon luteum Huds. Identification of L. galeobdolon is based on three main morphological features distinguishing it from other Lamium species: color of the corolla, the number and shape of lobes in the corolla's lower lip (Sychowa 1967; Ball 1972; Szafer et al. 1986; Krawczyk et al. 2013). It is debatable whether those key features are sufficient to place this taxon in separate genera. Opinions are divided, and taxonomists take different approaches to the problem. The comparison of nutlet micromorphology of $L$. galeobdolon with other Lamium species will enable determining whether the fruits of this species stand out against the tested genus.

\section{Materials and methods}

The study included 19 taxa of the genus Lamium, belonging to 14 species (Table 1 ). in the case of $L$. album subsp. album, L. amplexicaule and $L$. purpureum, the research material was collected in the course of our own field study. Other fruits were obtained from herbarium specimens, kindly provided by domestic and foreign herbaria: BR, COA, GJO, H, L, TUR. Three to four fully developed, mature and dry nutlets were examined for each taxon after a number of specimens had been compared under a light microscope for similarity. Nutlet length and width (Table 2) were measured in 20 samples per specimen of each taxon. The terminology of nutlet micromorphology was adopted after Barthlott (1981) and Salmaki et al. (2008).

Observations were done under Nikon SMZ1000 light microscope equipped with Nikon Digital Sight camera. Then, 3-4 Lamium fruits of each taxa were mounted on copper tables, and sputter-coated with gold in argon atmosphere (Fine coater JFC-1200, JEOL). Mericarp texture was imaged by a scanning electron microscope (JSM $5310 \mathrm{LV}, \mathrm{JEOL}$ ) at $15 \mathrm{kV}$ and analyzed by NSS Version 3.0 (EDS Noran System 7.0, Thermo Scientific). Light and electron microscopy allowed observing the structure of fruit surface but it was not possible to determine the origin of the protuberances present in mericarps of some species, macroscopically observed as whitish spots. Suspecting that these are thickenings of the cuticular layer, we performed cuticle and cutin staining according to the methodology of 
Table 1 Information about specimens used in the study; country of origin, year of collection, voucher information

\begin{tabular}{|c|c|c|c|}
\hline Species & Country & Year of collection & Barcode number \\
\hline L. album subsp. album L. & Poland & 2010 & - \\
\hline L. album subsp. barbatum (Siebold and Zucc) Mennema & Japan & 1968 & L 0790173 \\
\hline L. amplexicaule L. & Poland & 2009 & - \\
\hline L. bifidum subsp. balcanicum Velen & Greece & 1980 & BR 549820 \\
\hline L. bifidum subsp. bifidum Cirillo & France & 1990 & BR 5499274 \\
\hline L. confertum Fr. & Finland & 1988 & Н 675201 \\
\hline L. coutinhoi J.G.Garcia & Portugal & 2004 & COA 33918 \\
\hline L. flexuosum Ten. & Italy & 1968 & TUR 170353 \\
\hline L. garganicum subsp. corsicum (Gren. and Godr.) Mennema & Italy & 1978 & L 0790158 \\
\hline L. garganicum subsp. garganicum L. & Austria & 2008 & GJO 49925 \\
\hline L. garganicum subsp. laevigatum (Ces., Pass. and Gibelli) Arcang. & France & 1973 & H 1134555 \\
\hline L. garganicum subsp. striatum (Sm.) Hayek) & Serbia & 1968 & TUR 265431 \\
\hline L. gevorense (Gómez Hern.) Gómez Hern. and A.Pujadas & Spain & 2005 & COA 33931 \\
\hline L. incisum Willd. & Finland & 2009 & TUR 394510 \\
\hline L. macrodon Boiss. and A.Huet & Turkey & 1983 & Н 1490027 \\
\hline L. maculatum (L.) L. & Romania & 1988 & TUR 297792 \\
\hline L. moschatum Mill. & Greece & 1997 & H 1695935 \\
\hline L. orvala $\mathrm{L}$. & Slovenia & 1970 & TUR 246641 \\
\hline L. purpureum $\mathrm{L}$. & Poland & 2010 & - \\
\hline
\end{tabular}

Wędzony (1996), after Heslop-Harrison (1977). Dried seeds of Lamium were placed for $20 \mathrm{~min}$ in auramine $\mathrm{O}$ solution for cuticle localization (lit). The characteristic fluorescence (excitation $405 \mathrm{~nm}$, emission 470-520 nm) of cuticle was analyzed using a laser scanning microscope (LSCM, SP5, Leica), with LA AF Version: 2.4.1 build 6384. We examined fruits of $L$. amplexicaule with numerous spots and L. flexuosum, where spots were not observed.

\section{Results}

Morphological variation of the pericarp

Evaluation of Lamium mericarps under a light microscope revealed that their surface, colored in various shades of brown, was usually spotted with whitish, convex, shiny spots. Depending on the species, spots occurred singly or in large numbers, covering almost the entire surface of the fruit. Total absence of these spots was found only in the case of two species: L. flexuosum and L. orvala. Analysis of the smooth and spotted surface of fruits, carried out using confocal microscopy and appropriate staining, revealed cutin saturated cell walls and cuticular thickening present on their surface (Fig. 1). It was found that the protrusions seen as spots emitted fluorescent light, similarly to thickened parts of the cell wall in the area of smooth surfaces. It allows concluding that the observed structures were probably cuticular platelets.

Observation of fruit surface using SEM showed that the outer layer of the pericarp of species studied was formed by approximately isodiamteric, penta- to octagonal cells, forming reticulate surface sculpturi. L. moschatum was the only species where elongated cells were observed towards the axis of the mericarp (Fig. 2). Cell boundaries were generally straight or slightly undulated (due to the thickenings on the margins of cell walls). Anticlinal cell walls in most species were slightly channelled, although in some species (e.g., L. album, L. garganicum), an outline of the cells was difficult to observe because of the rich ornamentation of the surface of the fruit. Anticlinal walls of $L$. flexuosum and L. orvala were the only ones that were raised. The surfaces of the outer periclinal cell walls were usually concave, and cells with a flat surface were also observed in several taxa (Table 2). The margins of the periclinal walls were raised or flat. In some species, thickenings of the cell walls were present. They were regular (e.g., L. garganicum subsp. garganicum), ribbed (e.g. L. coutinhoi) or band-like, forming a ring on the periphery of the wall (e.g., L. maculatum).

The studied species can be divided into two main groups based on the secondary sculpturing of the cell walls observed. The first group consisted of species which cell wall 


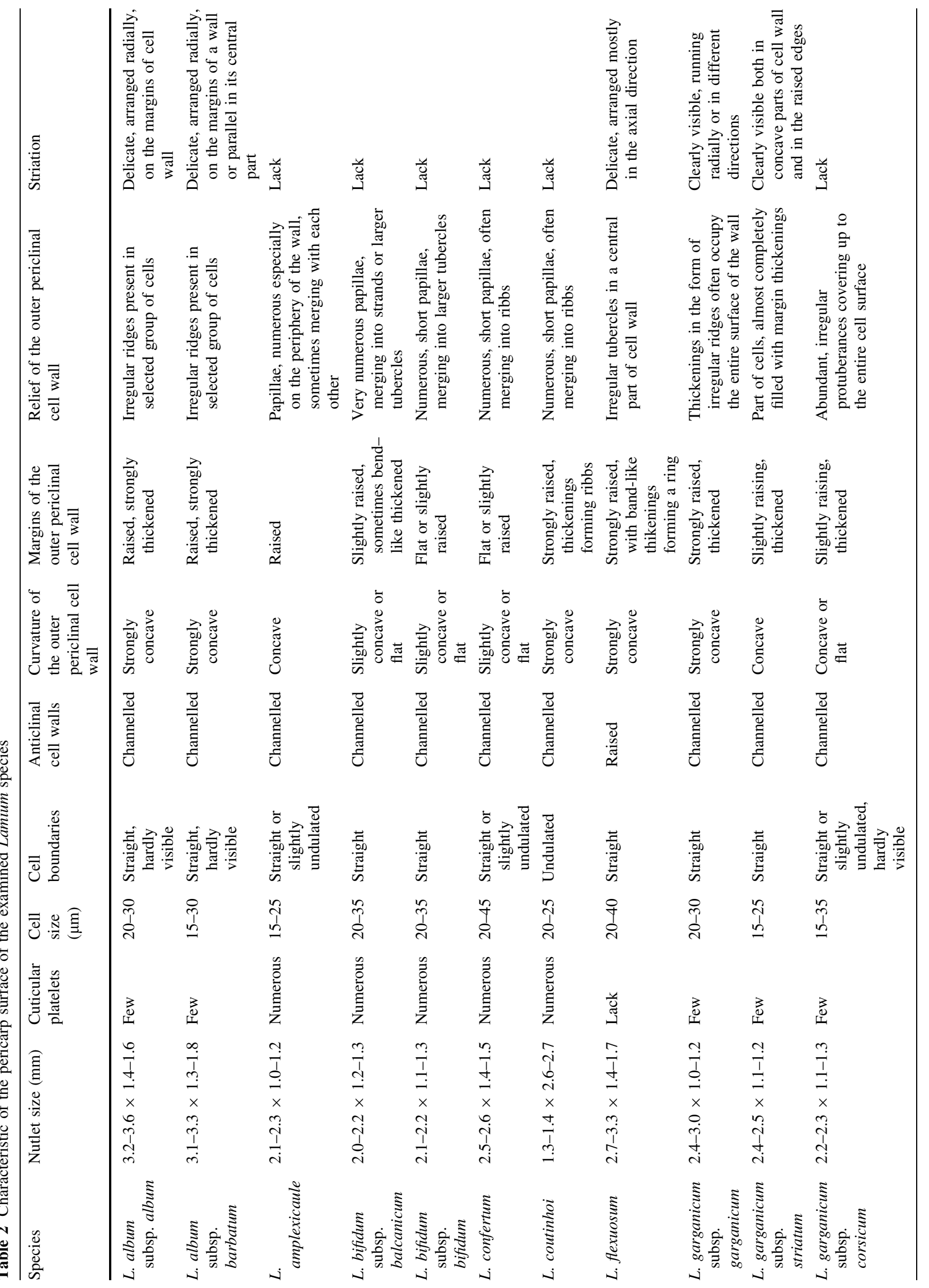




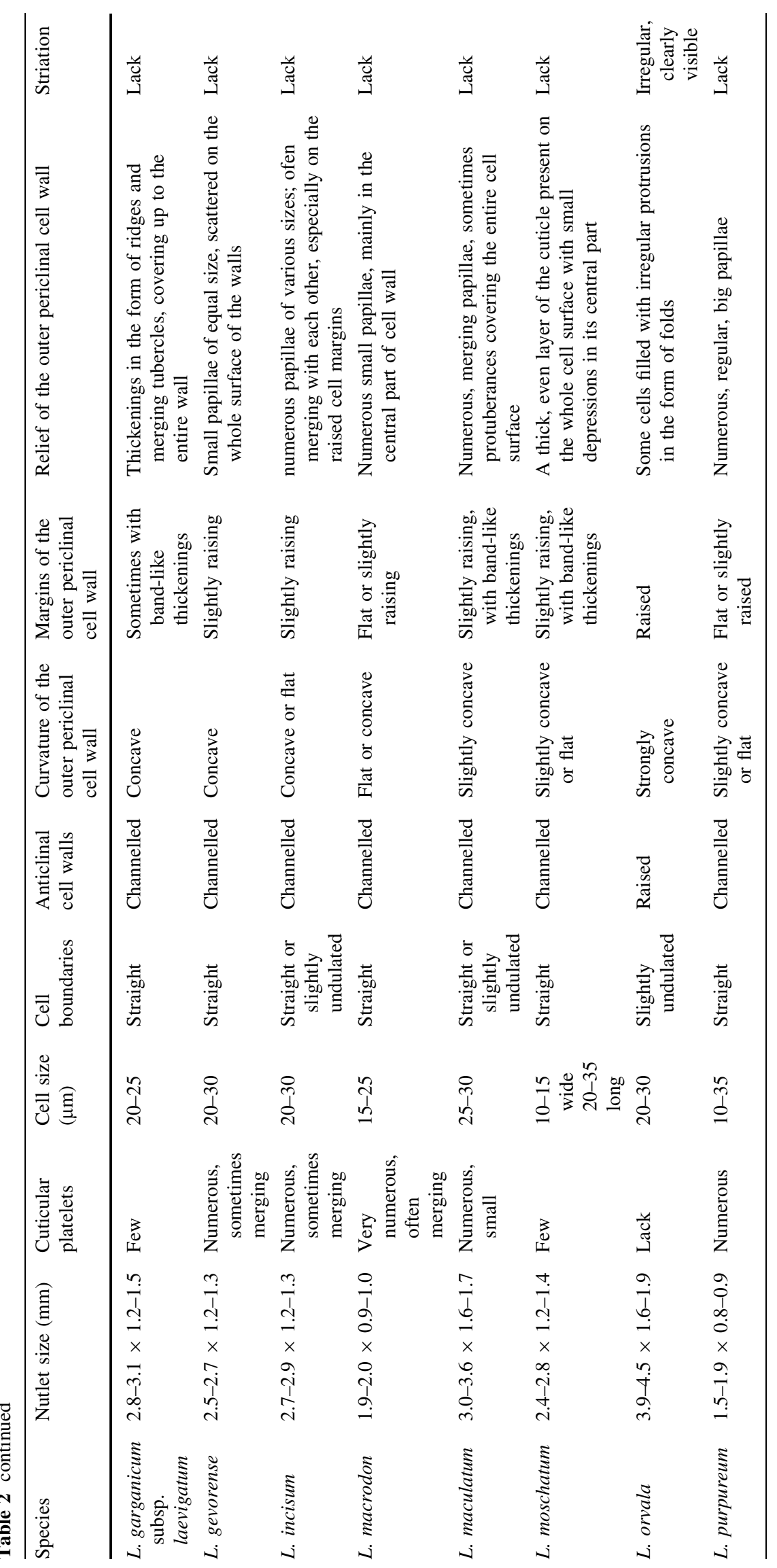



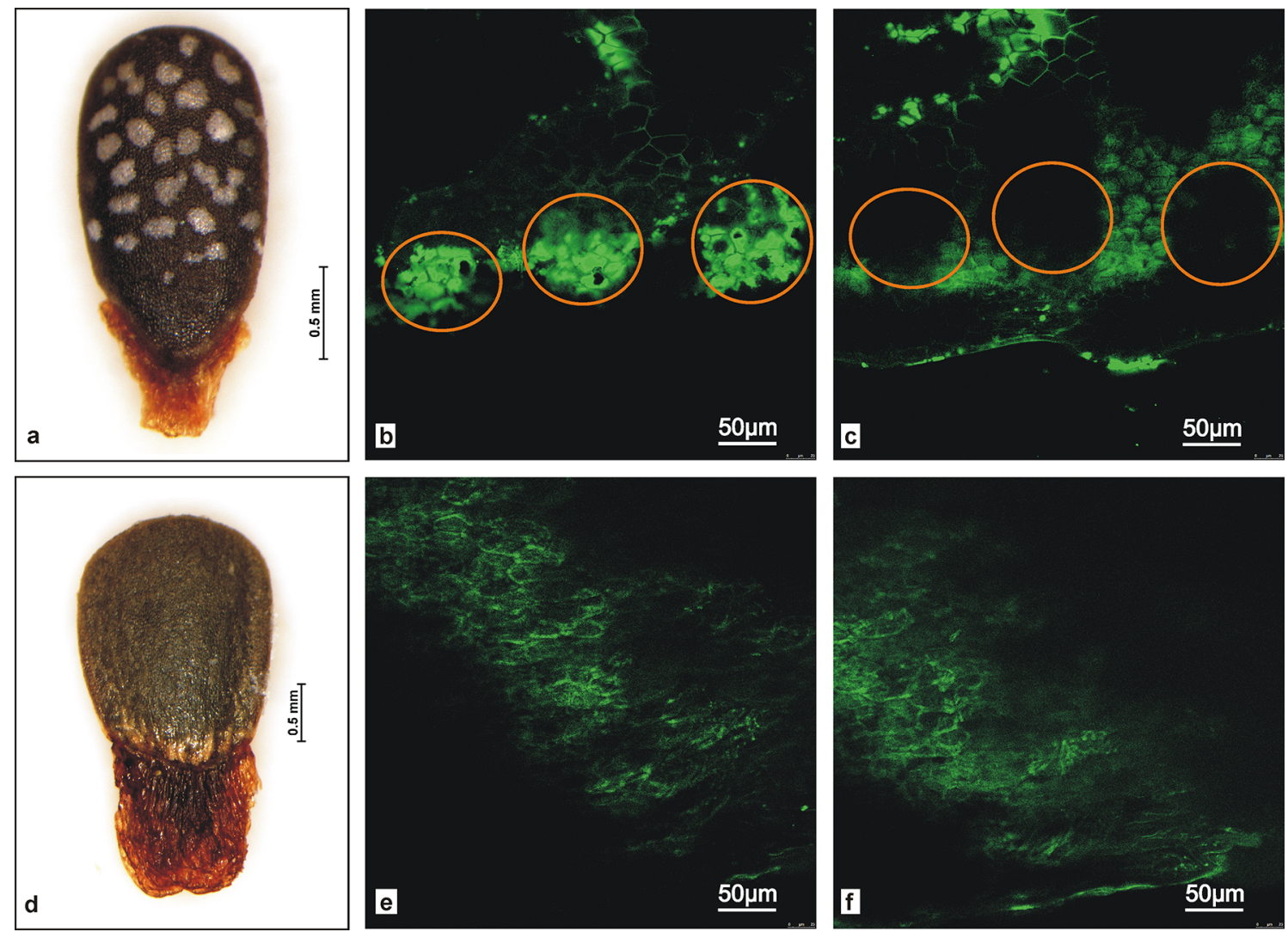

Fig. 1 Fruit surface of Lamium amplexicaule (a, b, c) and $L$. flexuosm (d, e, f) observed in light microscope (a, d) and laser scanning microscope $(\mathbf{b}, \mathbf{c}, \mathbf{e}, \mathbf{f})$. Wax platelets visible in $\mathbf{b}$ and $\mathbf{c}$ are marked with orange circles. Parts $\mathbf{b}$ and $\mathbf{e}$ present cuticle fluorescence observed for different values of $Z$ axis than figures $\mathbf{c}$ and $\mathbf{f}$

presence or absence of striation. In addition, individual taxa differed in the shape of the periclinal wall and the structure of thickenings present on this wall. The difference in ornamentation of the fruits was also observed in two subspecies of L. bifidum. Subspecies balcanicum had groups of cells with band-like thickened edges and low thickenings in the form of papillae as well as areas of cells densely covered with thickenings in the form of ridges (Fig. 3). In subspecies bifidum, there were no band-like thickenings on the margins of the walls. Surface of periclinal walls was covered with tubercles to a various extent, but they did not form ridges (Fig. 3). There were no micromorphological features observed in $L$. album that would allow identification of the distinguished subspecies.

Diagnostic features of species of hybrid origin

Comparison of sculpturing of nutlets of $L$. incisum and $L$. purpureum enabled defining traits that distinguish these two species. Papillae of different sizes were found on the surface of the pericarp cells in L. incisum that sometimes merged into larger tubercles. They were located mainly on the periphery of the external periclinal cell walls (Fig. 4). 

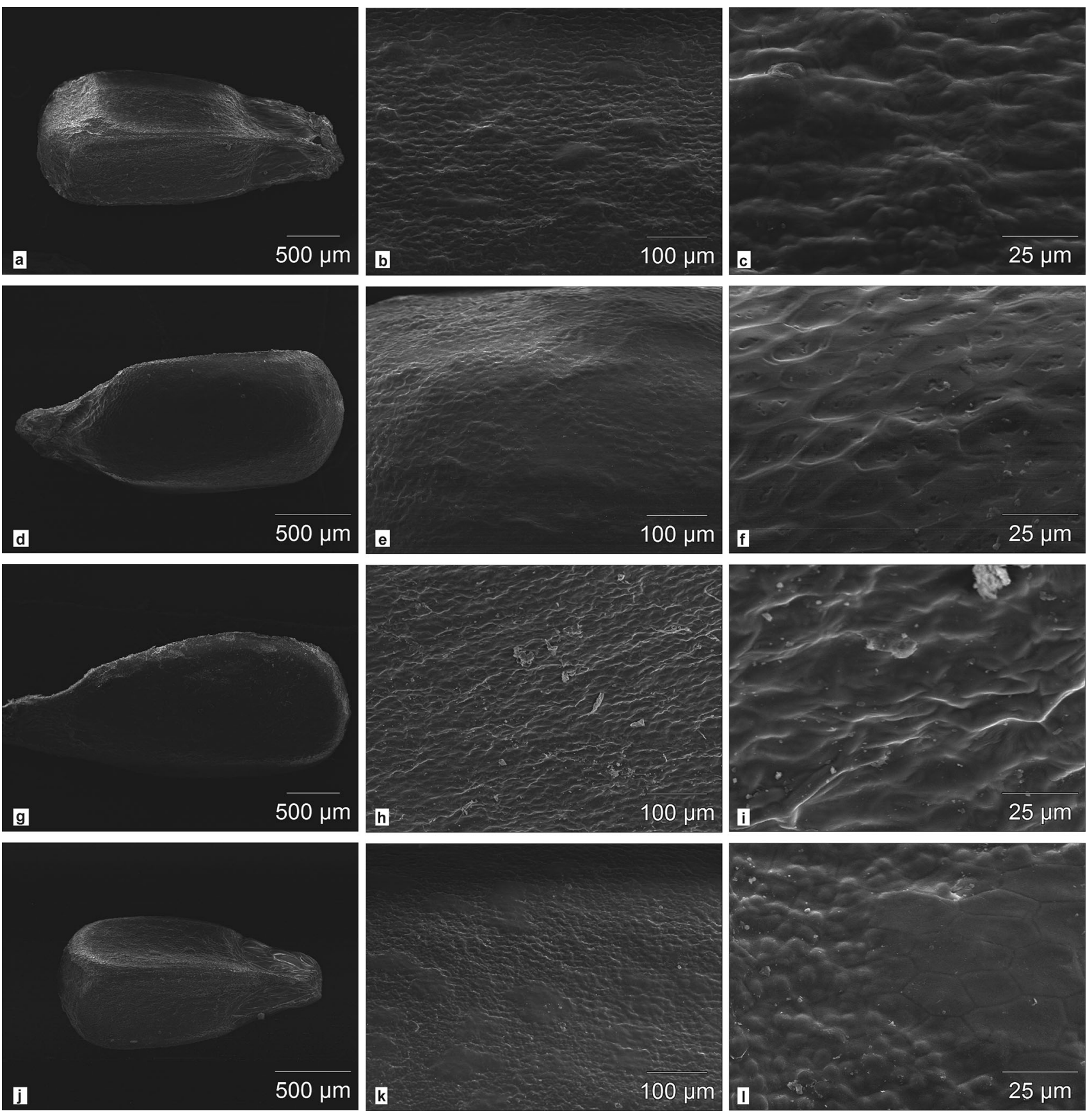

Fig. 2 SEM micrographs of mericarp surfaces in some taxa of Lamium: L. maculatum (a, b, c), L. moschatum (d, e, f), L. orvala (g, h, i), L. purpureum $(\mathbf{j}, \mathbf{k}, \mathbf{l})$

In L. purpureum, the papillae were large and evenly distributed over the entire surface of the cell wall (Fig. 2), which differentiated this species from $L$. incisum.

Features that distinguish $L$. confertum from $L$. amplexicaule were also identified. In these species they were also related to the protuberances on the surface of cells. Papillae of various sizes were present in $L$. confertum, merging on the edges of cells into ribbed structures (Fig. 5). L. amplexicaule had specific small papillae of equal size, distributed fairly evenly but they were slightly more numerous on the margins of the cell walls (Fig. 3).

When discussing micromorphological features specific for mericarps of $L$. confertum, one should pay attention to their very strong resemblance to the fruits of $L$. coutinhoi. The structures observed on the surface of mericarps of both species were similar to each other to such a degree that the distinction of species based on these traits was, in our opinion, impossible (Fig. 5). 

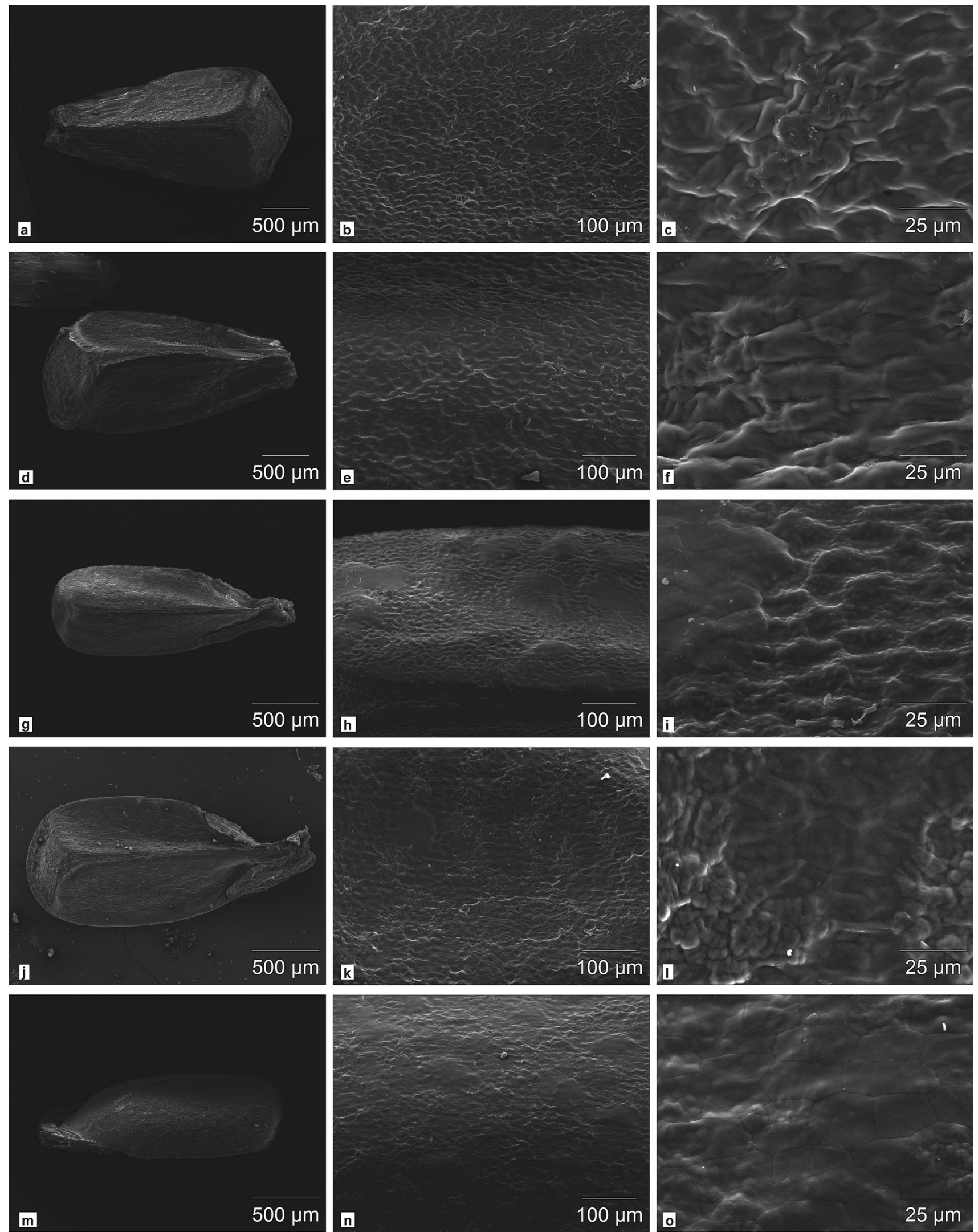

Fig. 3 SEM micrographs of mericarp surfaces in some taxa of Lamium: L. album subsp. album (a, b, c), L. album subsp. barbatum (d, e, f), L. amplexicaule (g, h, i), L. bifidum subsp. balcanicum $(\mathbf{j}, \mathbf{k}, \mathbf{l})$, L. bifidum subsp. bifidum (m, $\mathbf{n}, \mathbf{o})$ 


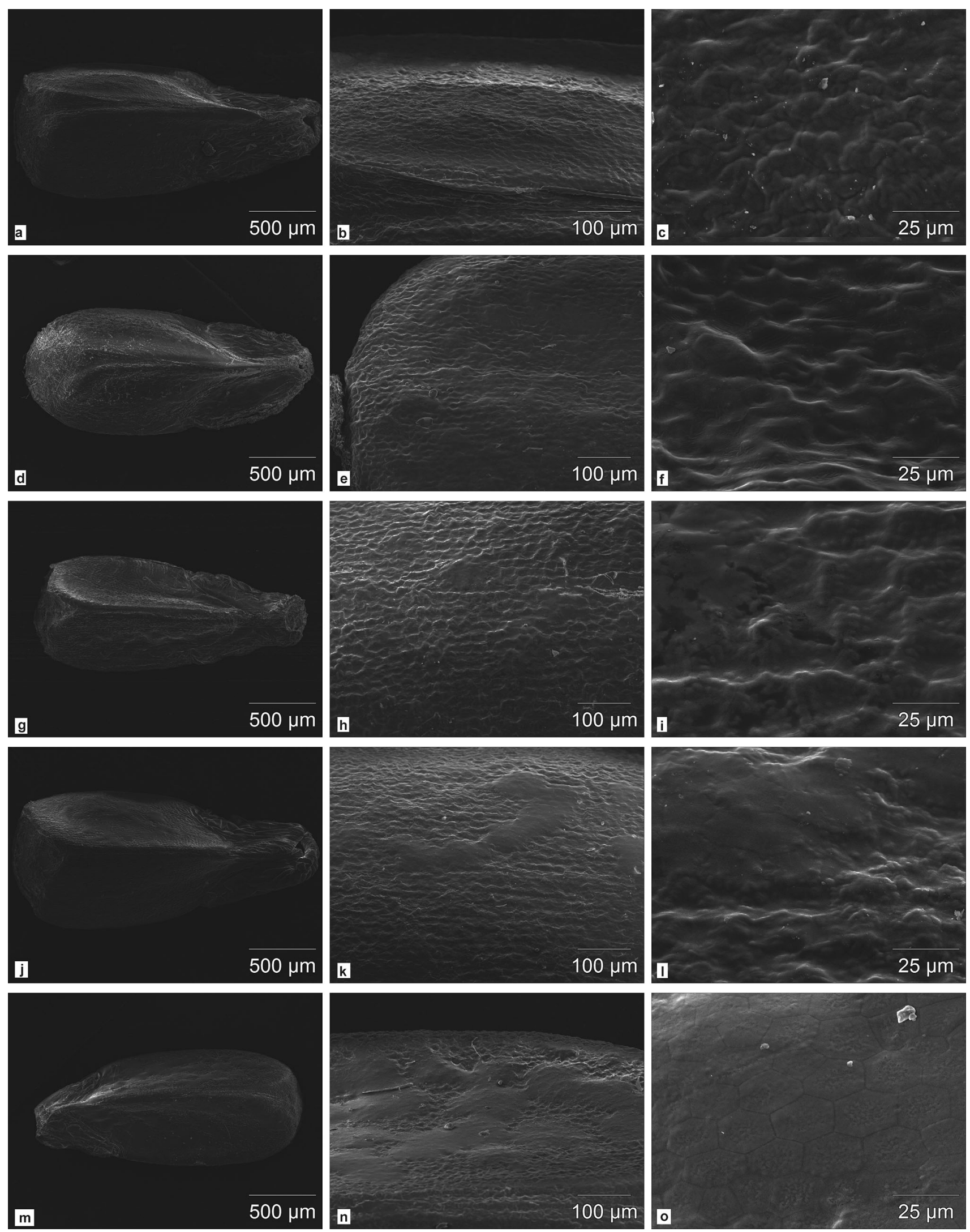

Fig. 4 SEM micrographs of mericarp surfaces in some taxa of Lamium: L. garganicum subsp. laevigatum (a, b, c), L. garganicum subsp. striatum (d, e, f), L. gevorense $(\mathbf{g}, \mathbf{h}, \mathbf{i})$, L. incisum $(\mathbf{j}, \mathbf{k}, \mathbf{l})$, L. macrodon $(\mathbf{m}, \mathbf{n}, \mathbf{o})$ 

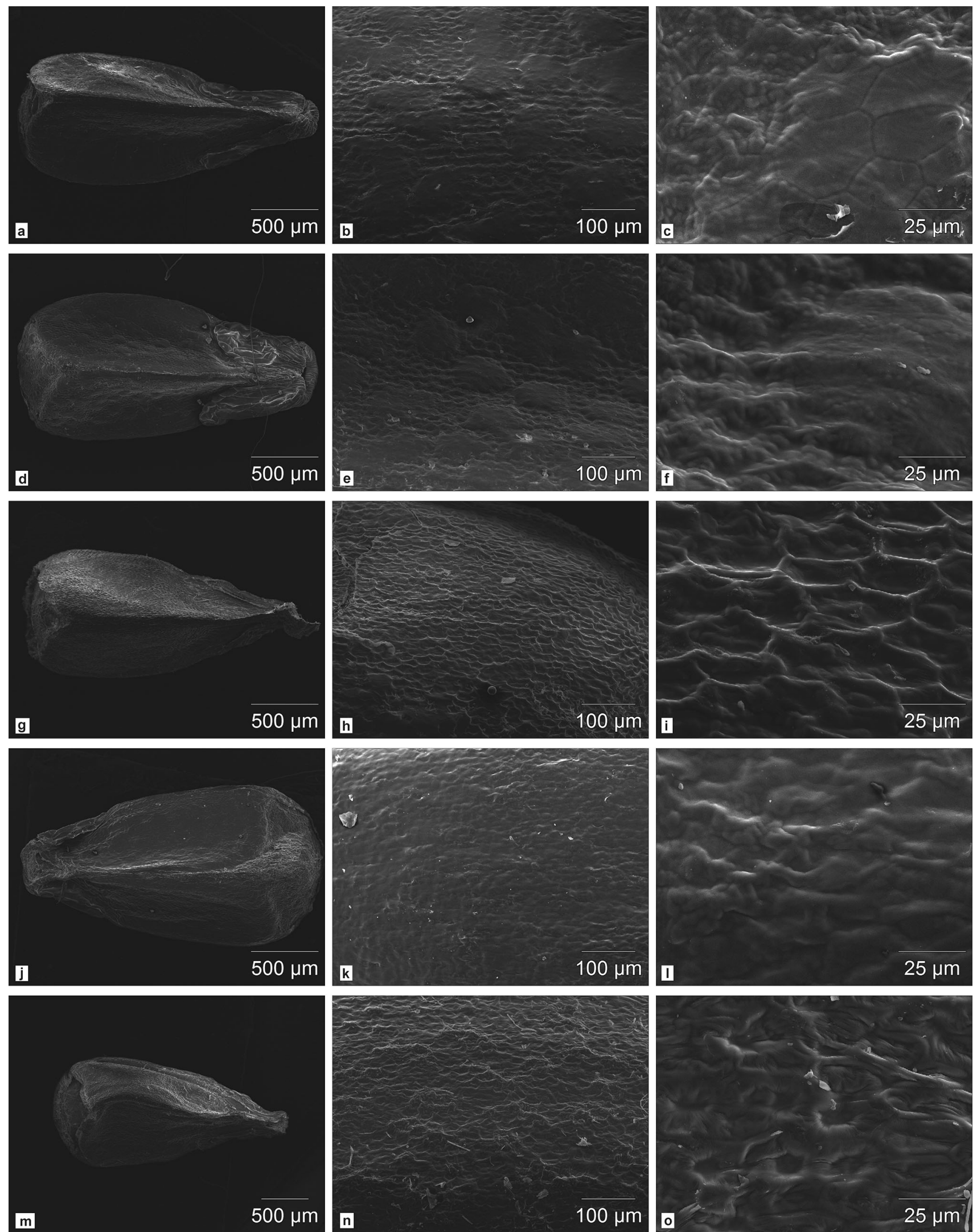

Fig. 5 SEM micrographs of mericarp surfaces in some taxa of Lamium: L. confertum (a, b, c), L. coutinhoi (d, e, f), L. flexuosum (g, h, i), L. garganicum subsp. corsicum $(\mathbf{j}, \mathbf{k}, \mathbf{l})$, L. garganicum subsp. garganicum $(\mathbf{m}, \mathbf{n}, \mathbf{o})$ 


\section{Discussion}

Our results showed that L. flexuosum and L. orvala differed to a large extent from other Lamium species. At the same time, a comparison of the characteristics of nutlets of $L$. flexuosum and L. orvala to the description of fruits of $L$. galeobdolon (Czarna and Bednorz 2011), indicated a high similarity of these three species. Their common features included a lack of cuticular plates, a lack of cell wall thickening in the form of papillae, the presence of striations and convex anticlinal cell walls. Furthermore, the analysis of pericarp morphology revealed no significant differences between L. galeobdolon and the remaining species from the Lamium genus. Quite the contrary, there were many common features indicating the similarity of mericarps of $L$. galeobdolon and the other dead-nettles, in particular $L$. flexuosum and L. orvala. The observed similarity can be explained by the evolutionary history of the species studied. The results of phylogenetic studies showed that $L$. galeobdolon did not form a separate phylogenetic line in relation to the genus Lamium and thereby confirmed that the presence of L. galeobdolon in Lamium was justified (Krawczyk et al. 2013; Krawczyk and Sawicki 2013). Molecular studies confirmed a close relationship of $L$. flexuosum, L. galeobdolon and L. orvala (Krawczyk et al. 2014). The infrageneric classification based on macromorphological features also emphasizes the similarity of $L$. galeobdolon and L. flexuosum which constitute the subgenus Galeobdolon, while L. orvala belongs to the monospecific subgenus Orvala (Mennema 1989).

The results of molecular studies were congruent with the observed morphological variability of pericarp also with respect to the status of $L$. garganicum subsp. laevigatum. The difference noticed in sculpturing of the fruits of this taxon compared to second subspecies of L. garganicum is an argument to consider L. garganicum subsp. laevigatum a separate taxon. This result is consistent with the analysis of variation of barcoding sequences in the genus Lamium, which also indicated the distinctiveness of this subspecies (Krawczyk et al. 2014; Krawczyk and Sawicki 2013).

Our findings showed that the analysis of fruit surface with the use of SEM allowed defining new diagnostic features for almost all studied representatives of the genus Lamium. Many of the variable nutlet characters have been shown to be diagnostic and of systematic value in other groups of Lamiaceae (Husain et al. 1990; Oran 1996; Salmaki et al. 2008). However particular features were of different taxonomic values depending on the studied group of plants. Among different nutlet characters studied, the type of sculpturing has been considered to provide the most valuable ones (Oran 1996). In Lamium, the general nutlet surface patterns described by Salmaki et al. (2008) showed rather low diagnostic value, since all the species studied within the genus were characterized by more or less reticulate sculpture. Only the thorough analysis of details of pericarp surface sculpturing provided valuable data for delimitation of dead-nettle species.

As noted by Barthlott (1981), cuticle striation is usually a valuable diagnostic feature. However the importance of this character in the identification of taxa higher than species seems to be limited. In turn, cell wall thickenings are both of diagnostic and taxonomic importance. According to Barthlott (1981), these structures most often distinguish taxa at the level of the genus and subfamily. Our results confirmed Barthlott's observations. The type of cell wall thickening observed in the pericarp of Lamium divided the species studied into groups, which largely coincided with phylogenetic lines distinguished in the genus studied (Krawczyk and Sawicki 2013). Sculpturing of the cell walls in the form of papillae arose independently in two phylogenetic lines. One of them consists of: L. amplexicaule, L. bifidum, L. gevorense and L. incisum, while the second one comprises: L. confertum, L. coutinhoi, $L$. maculatum and L. purpureum. The papillae also evolved in the species L. macrodon, closely related to L. moschatum. The lack of visible cell wall thickening in L. moschatum may be the result of speciation. However, it cannot be ruled out that the cell wall thickenings are present in this species, but they are invisible due to the thick layer of cuticle on the surface of the fruit.

\section{Conclusion}

Nutlet micromorphology provides diagnostic features for almost all representatives of Lamium included in this study. One of the most valuable features, useful in distinguishing examined species, is cuticle striation, while cell wall thickenings are both of diagnostic and taxonomic importance. Although the analysis of fruit surfaces does not resolve phylogeny of the genus completely, it confirms to a large extent the picture of phylogenetic relationships derived from molecular studies. The obtained results combined with the analysis of macromorphological features and the results of phylogenetic studies provide a sound basis for creating a new taxonomical classification within the genus Lamium. However, in our opinion, a thorough reanalysis of macromorphological features is necessary to establish such a classification.

Acknowledgments We are grateful to Herbarium Curators of the following institutions for making their collections available: National Botanic Garden of Belgium (BR); Botanical Garden in Cordoba (COA); Herbarium des Steiermark. Landesmuseum Joanneum (GJO); Finish Museum of Natural History, Botanical Museum (H); Nationaal Herbarium Nederland (L); Herbarium Cepartment of Biology University of Turku (TUR). The study was made possible through 
financial support from the National Centre of Science (Grant 2011/01/ $\mathrm{N} / \mathrm{NZ8/02208).}$

Open Access This article is distributed under the terms of the Creative Commons Attribution License which permits any use, distribution, and reproduction in any medium, provided the original author(s) and the source are credited.

\section{References}

Arcangeli G (1882) Compendio della flora italiana; ossia, Manuale per la determinazione delle piante che trovansi selvatiche od inselvatichite nell'Italia e nelle isole adiacenti, Torino. doi:10. 5962/bhl.title.9995

Ball PW (1972) Lamium L. In: Tutin TG, Heywood VH, Burges NA, Moore DM, Valentine DH, Walters SM, Webb DA (eds) Flora Europaea, vol 3. Cambridge, pp 147-148

Barthlott W (1981) Epidermal and seed surface characters of plants: systematic applicability and some evolutionary aspects. Nordic $\mathbf{J}$ Bot 1:345-355. doi:10.1111/j.1756-1051.1981.tb00704.x

Barthlott W, Voit G (1979) Mikcromorphologie der Samenschalen und Taxonomie der Cactaceae: ein raster-elektronenmikroskopischer Überblick. Pl Syst Evol 132:205-229

Bendiksby M, Brysting AK, Thorbek L, Gussarova G, Ryding O (2011) Molecular phylogeny and taxonomy of the genus Lamium L. (Lamiaceae): disentangling origins of presumed allotetraploids. Taxon 60:986-1000

Budantsev AL, Lobova TA (1997) Fruit morphology, anatomy and taxonomy of tribe Nepeteae (Labiatae). Edinburgh $\mathrm{J}$ Bot 54:183-216. doi:10.1017/S0960428600004029

Czarna A, Bednorz L (2011) New diagnostic features of taxa within Lamium subg. Galeobdolon (Lamiaceae). Roczn Akad Roln Poznaniu 390. Bot Stec 15:49-51

Demissew S, Harley MM (1992) Trichome, seed surface and pollen characters in Stachys, Lamioideae (Labiatae) in Tropical Africa. In: Harley RM, Reynolds T (eds) Advances in Labiatae science. Royal Botanic Gardens, Kew, pp 149-166. doi:10.1016/j.flora. 2008.11.001

Dvořáková M (2000) Lamium L.-hluchavka. In: Slavík B (ed) Květena České Republiky, vol. 6. Praha, pp 596-603

Govaerts R, Paton A, Harvey Y, Navarro T (2010) World checklist of Lamiaceae and Verbenaceae. Available at: http://www.kew.org/ wcsp/lamiaceae. Accessed 21 November 2013

Guerin GR (2005) Nutlet morphology in Hemigenia R.Br. and Microcorys R.Br. (Lamiaceae). Pl Syst Evol 254:49-68. doi:10. 1007/s00606-005-0311-y

Heslop-Harrison Y (1977) The pollen-stigma interaction: pollen-tube penetration in Crocus. Ann Bot (Oxford) 41:913-922

Husain SZ, Marin PD, Šilic C, Qaiser M, Petković B (1990) A micromorphological study of some representative genera in the tribe Saturejeae (Lamiaceae). Bot J Linn Soc 103:59-80. doi:10. 1111/j.1095-8339.1990.tb00174.x

Jamzad Z, Harley MM, Ingrouille M, Simmonds MSJ, Jalili A (2000) Pollen exine and nutlet surface morphology of the annual species of Nepeta L. (Lamiaceae) in Iran. In: Harley MM, Morton CM, Blackmore S (eds) Pollen and spores: morphology and biology. Kew, pp 385-397

Jörgensen CA (1927) Cytological and experimental studies on the genus Lamium. Hereditas 9:126-136. doi:10.1111/j.1601-5223. 1927.tb03514.x
Kahraman A, Celep F, Doğan M, Guerin GR, Bagherpour S (2011) Mericarp morphology and its systematic implications for the genus Salvia L. section Hymenosphace Benth. (Lamiaceae) in Turkey. Pl Syst Evol 292:33-39. doi:10.1007/s00606-010-0394-y

Krawczyk K, Sawicki J (2013) The uneven rate of the molecular evolution of gene sequences of DNA-Dependent RNA polymerase $\mathrm{I}$ of the genus Lamium L. Int $\mathrm{J}$ Molec Sci 14(6):11376-11391. doi:10.3390/ijms140611376

Krawczyk K, Korniak T, Sawicki J (2013) Taxonomic status of Galeobdolon luteum Huds. (Lamiaceae) from classical taxonomy and phylogenetics perspectives. Acta Biol Cracov Ser Bot 55(2):18-28. doi:10.2478/abcsb-2013-0016

Krawczyk K, Szczecińska M, Sawicki J (2014) Evaluation of 11 single-locus and seven multi-locus DNA barcodes in Lamium L. (Lamiaceae). Mol. Ecol Res 14(2):272-285. doi:10.1111/17550998.12175

Marin PD, Petković BP, Duletić S (1994) Nutlet sculpturing of selected Teucrium species (Lamiaceae): a character of taxonomic significance. Pl Syst Evol 192:199-214. doi:10.1007/ BF00986252

Marin PD, Duletić S, Petković B (1996) Nutlet ornamentation in selected Salvia L. species (Lamiaceae). Fl Medit 6:203-211

Mennema J (1989) A taxonomic revision of Lamium. PhD Thesis. Leiden University, Leiden

Mirek Z, Piękoś Mirkowa H, Zając A, Zając M (eds) (2002) Flowering plants and pteridophytes of Poland-a checklist. W. Szafer Institute of Botany, Polish Academy of Sciences, Kraków

Moon HK, Hong SP (2006) Nutlet morphology and anatomy of the genus Lycopus (Lamiaceae: Menthae). J Pl Res 119:63-644. doi:10.1007/s10265-006-0023-6123

Oran SA (1996) Ultrastructure of nutlet surface of the genus Salvia L. in Jordan and the neighbouring countries. Dirasat Nat Engin Sci 23:393-408

Rothmaler W (2007) Exkursionsflora von Deutschland. Elsevier, München

Ryding O (1992) Pericarp structure and phylogeny within Lamiaceae subfamily Nepetoideae tribe Ocimeae. Nordic J Bot 12:273-298. doi:10.1111/j.1756-1051.1992.tb01304.x

Ryding O (1994) Pericarp structure and phylogeny of Lamiaceae subfamily Pogostemonoideae. Nordic J Bot 14:59-63. doi:10. 1111/j.1756-1051.1994.tb00572.x

Ryding O (1995) Pericarp structure and phylogeny of LamiaceaeVerbenaceae complex. Pl Syst Evol 198:101-141. doi:10.1007/ BF00985109

Salmaki Y, Zarre S, Jamzad Z (2008) Nutlet micromorphology and its systematic implication in Stachys L. (Lamiaceae) in Iran. Feddes Repert 119:607-621. doi:10.1002/fedr.200811187

Satıl F, Kaya A, Akçiçek E, Dirmenci T (2012) Nutlet micromorphology of Turkish Stachys sect. Eriostomum (Lamiaceae) and its systematic implications. Nordic J Bot 30:352-364. doi:10. 1111/j.1756-1051.2011.01306.x

Sychowa M (1967) Galeobdolon Adans. In: Pawłowski B (ed) Flora Polska, Rośliny Naczyniowe Polski i Ziem Ościennych. Instytut Botaniki Polskiej Akademii Nauk, Warszawa-Kraków

Szafer W, Kulczyński S, Pawłowski B (1986) Rośliny Polskie. Wydawnictwo Naukowe PWN, Warszawa

Taylor R (1991) The origin of Lamium hybridum, a case study in the search for the parents of hybrid species. Northw Sci 65:116-124

Wędzony M (1996) Mikroskopia fluorescencyjna dla botaników. PAN Zakład Fizjologii Roślin im, Franciszka Górskiego, Kraków 